\title{
Pengaruh Lioprotektant Terhadap Karakteristik Nanopartikel Artesunat-Kitosan Yang Dibuat Dengan Gelasi Ionik-Pengeringan Beku
}

\author{
Abhimata Paramanandana, Retno Sari*, Pawahid, Erika A. Novarinandha \& Widji Soeratri \\ Fakultas Farmasi Universitas Airlangga Surabaya \\ *Corresponding author: retno-s@ ff.unair.ac.id
}

\begin{abstract}
Background: Nanoparticles are particles with a diameter range between 1 - $1000 \mathrm{~nm}$. Artesunate-chitosan nanoparticles made using ionic gelation-freeze dry method intended to protect the drug from degredation during the manifacturing process. To obtain an excelent freeze dried product, it is necessary to optimize the use of lioprotektant. Objective: The aim of this study is to learn the physical characterization of freeze dried artesunatchitosan nanoparticles prepared using three different lyoprotectant: sucrose, trehalose and maltodextrin. Methods: Nanoparticles were prepared by ionic gelation method using tripolyphosphate as crosslinker. Dried nanoparticles evaluated for its morphology, physical state, infrared spectra and redispersability. Results: Deferential thermal analysis (DTA) thermogram showed that by adding lyoprotectants, artesunate remain entrapped in chitosan nanoparticle system, while without lyoprotectants no artesunat were entraped in the chitosan matrix. The morphological observations using scanning electron microscopy (SEM) showed that artesunate-chitosan nanoparticles with $2.5 \%$ maltodextrin have smooth surface and spherical structure. In addition, maltodextrin shows better protection during freeze drying, slower particle precipitation and better particle redispersibility compared to particles with sucrose and trehalose. Lyoprotectants with large concentration indicates better redispersabilty of artesunate-chitosan nanoparticles. Conclusions: Based on the results, it can be concluded that the addition of lyoprotectant affect the characteristics of artesunate-chitosan nanoparticles.
\end{abstract}

Keywords: nanoparticles, artesunate, lyoprotectant, ionic gelation, freeze dry

\begin{abstract}
Abstrak
Latar belakang: Nanopartikel merupakan partikel dengan rentang ukuran diameter antara $1-1000 \mathrm{~nm}$. Nanopartikel Artesunat-Khitosan diformulasikan menjadi nanopartikel menggunakan metode gelasi ionikpengering beku ditujukan untuk melindungi bahan obat dari peruraian selama proses pembuatan. Untuk memperoleh produk dari pengeringan beku yang baik, optimasi lioprotektan sangat diperlukan. Tujuan: Tujuan dari penelitian ini adalah untuk mempelajari karakteristik fisik nanopartikel Artesunat-Khitosan yang diformulasikan dengan tiga lioprotektan yang berbeda: sukrosa, trihalosa dan maltodekstrin menggunakan metode pengeringan beku. Metode: Pembuatan nanopartikel dilakukan menggunakan gelasi ionik dengan tripolifosfat sebagai crosslinker. Evaluasi nanopartikel kering meliputi: morfologi, sifat fisik, spektrum inframerah dan redispersabilitas. Hasil: Data deferential thermal analysis (DTA) menunjukkan, penambahan lioprotektan menjebak artesunat dalam sistem nanopartikel chitosan, dimana formula tanpa penambahan lioprotektan tidak ditemukan artesunat di dalam matriks chitosan. Pemeriksaan morfologi menggunakan scanning electron microscopy (SEM) menunjukkan nanopartikel dengan 2,5\% maltodextrin memiliki permukaan yang halus dan bentuk yang speris. Selain itu, maltodextrin menunjukkan efek perlindungan selama pengeringan beku, laju pengendapan yang lebih lambat dan kemampuan untuk redipersi yang lebih baik dibandingkan dengan sukrosa dan trehalosa. Lioprotektan dengan konsentrasi tinggi menunjukkan redispersibilitas nanopartikel artesunat-chitosan yang lebih baik. Kesimpulan: Berdasarkan hasil penelitian ini, dapat disimpulkan bahwa dengan penambahan lyoprotectant mempengaruhi karakterisitik nanopartikel artesunat-chitosan.
\end{abstract}

Kata kunci: nanopartikel, artesunat, lioprotektan, gelasi ionic, pengeringan beku 


\section{PENDAHULUAN}

Nanopartikel merupakan partikel dengan rentang ukuran diameter antara $1-1000 \mathrm{~nm}$. Matriks nanopartikel terdiri dari polimer dapat berasal baik dari polimer alam maupun polimer sintesis (Abdelwahed dkk., 2006; Bernard \& Stainmesse, 2007). Salah satu polimer yang berasal dari alam, kitosan, memiliki gugus amino bebas yang bermuatan positif. Interaksi elektrostatik dapat terbentuk antara gugus amino kitosan dengan penyambung silang anion multivalent tripolifosfat (TPP) melalui metode gelasi ionic (Tiyaboonchai, 2003). Penambahan polivinil alkohol (PVA) sebagai stabilisator dapat meningkatkan stabilitas koloid nanopartikel (Hasan, 2012) dengan cara mencegah agregasi melalui pembentukan lapisan polimer pada permukaan partikel serta meningkatkan ketahanan pembekuan pada saat pengeringan beku (Darwin dkk., 2007; Hirsjärvi, 2008; Date, Samad \& Devarajan, 2010).

Pengeringan beku bertujuan dilakukan untuk meningkatkan stabilitas jangka panjang dari koloid nanopartikel. Pengeringan beku dapat menghasilkan beberapa tekanan yang dapat menyebabkan koloid nanopartikel menjadi tidak stabil, khususnya tekanan saat pembekuan (Abdelwahed et al., 2006; Bernard \& Stainmesse, 2007). Faktor yang berpengaruh pada karakteristik dan porositas nanopartikel pada proses pengeringan yaitu suhu dan waktu pembekuan, suhu dan waktu pengeringan, jenis dan jumlah lioprotektan, dan volume air yang ditambahkan (Abdelwahed dkk., 2006; Bernard \& Stainmesse, 2007; Garg dkk., 2011).

Lioprotektan memiliki kemampuan untuk melindungi nanopartikel dari tekanan saat pembekuan. Kelompok gula seperti sukrosa, trihalosa dan maltodekstrin memiliki mekanisme perlindungan yang berasal dari matriks amorf yang terbentuk oleh gula seiring dengan hilangnya air pada saat pengeringan. Mekanisme perlindungan gula terdiri atas mekanisme vitrifikasi dan mekanisme penggantian air (water replacement), yaitu dengan cara membentuk ikatan hidrogen pada nanopartikel untuk menghambat kerusakan nanopartikel oleh kristal es (Corveleyn \&
Remon, 1996; Chang dkk., 2005; Abdelwahed dkk., 2006; Bernard \& Stainmesse, 2007; Varshosaz \& Karimzadeh, 2007; Amorij dkk., 2008; Akhilesh, Faishal \& Kamath, 2012).

Penelitian ini bertujuan untuk mengetahui pengaruh lioprotektan sukrosa, trehalosa dan maltodekstrin terhadap karakteristik fisik nanopartikel kitosan dengan bahan aktif artesunat. Nanopartikel dibuat dengan metode gelasi ionik menggunakan tripolifosfat sebagai penyambung silang, yang kemudian dikeringbekukan dengan penambahan tiga jenis lioprotektan (sukrosa, trehalosa, dan maltodekstrin) dengan berbagai jumlah. Nanopartikel kering dievaluasi meliputi pemeriksaan morfologi, jarak lebur, spektrum inframerah, dan kemampuan pendispersian partikel.

\section{BAHAN DAN METODE Bahan}

Artesunat (Goldliloo Pharmaceutical, China), maltodekstrin (Sorini Agro Asia Corporindo); sukrosa, trehalose; kitosan pharmaceutical grade (Biotech Surindo); sodium trifosfat pentabasic practical grade (Nacalai Tesque); asam asetat pro analisis; etanol proanalysis; aquadest.

Alat

Freeze Dryer $\left(\right.$ Christ $^{\mathrm{R}}$ Beta 1-8 K); Neraca analitik (Electronic Balance Chyo JP-160); Spektrofotometer inframerah (Jasco FT-IR 5300); Mettler Toledo FP-65 DTA P-900 Thermal; Brookfield Viscosimeter DV-II; Hettich Rotofix 32A Benchtop Centrifuge; mikroskop optik (Olympus IX71 Inverted Fluorescent Microscope); magnetic stirrer (DRAGONLAB MSPro) Scanning Electro Microscope (Inspect S50 tipe TP 2017/12).

\section{Metode}

\section{Rancangan formula}

Dalam penelitian ini, nanopartikel kitosan dibuat dengan metode gelasi ionik dan menggunakan proses pengeringan beku dengan menambahkan sukrosa, trihalosa dan maltodekstrin sebagai lioprotektan. 
Tabel 1. Rancangan formula nanopartikel artesunat-kitosan dengan lioprotektan sukrosa (S), trihalosa (T) dan maltodekstrin (M)

\begin{tabular}{|c|c|c|c|c|c|c|c|c|c|c|c|}
\hline \multirow{2}{*}{ Nama bahan } & \multicolumn{11}{|c|}{ Formula } \\
\hline & $\mathbf{K}^{*}$ & S1 & S2 & S3 & M1 & M2 & M3 & T1 & $\mathbf{T 2}$ & T3 & T4 \\
\hline Artesunat (mg) & 40 & 40 & 40 & 40 & 40 & 40 & 40 & 40 & 40 & 40 & 40 \\
\hline Kitosan (mg) & 100 & 100 & 100 & 100 & 100 & 100 & 100 & 100 & 100 & 100 & 100 \\
\hline TPP (mg) & 80 & 80 & 80 & 80 & 80 & 80 & 80 & 80 & 80 & 80 & 80 \\
\hline PVA (mg) & 50 & 50 & 50 & 50 & 50 & 50 & 50 & 50 & 50 & 50 & 50 \\
\hline Sukrosa $(\%)$ & - & 2,5 & 5 & 10 & - & - & - & - & - & - & - \\
\hline Maltodekstrin (\%) & - & - & - & - & 2,5 & 5 & 10 & - & - & - & - \\
\hline Trehalosa (\%) & & & & & & & & 2,5 & 3,5 & 7,5 & 10 \\
\hline
\end{tabular}

\section{Pembuatan nanopartikel kitosan}

Nanopartikel kitosan dibuat dengan metode gelasi ionik dengan perbandingan kitosan:TPP $=10: 8$ dengan cara:

Sejumlah kitosan didispersikan secara merata ke dalam larutan asam asetat $0,15 \%$ sambil diaduk dengan kecepatan $500 \mathrm{rpm}$ menggunakan magnetik stirer sampai larut (larutan kitosan $0,1 \% \mathrm{~b} / \mathrm{v}$ ). Selanjutnya kedalam larutan kitosan dimasukkan larutan TPP dan diaduk pada $500 \mathrm{rpm}$ selama dua jam. Setelah terbentuk koloid, dilakukan sentrifus untuk memisahkan antara padatan koloid dan filtrat. Setelah proses pemisahan padatan, selanjutnya dilakukan pengeringan beku dengan dan tanpa penambahan lioprotektan pada berbagai kadar sesuai rancangan formula pada Tabel 1 menggunakan Freeze Dryer $\left(\right.$ Christ $^{\mathrm{R}}$ Beta $\left.1-8 \mathrm{~K}\right)$ selama 24 jam sehingga didapatkan partikel kering.

\section{Evaluasi karakterisasi partikel kitosan}

\section{Morfologi permukaan nanopartikel}

Sampel diletakkan diatas holder yang telah dilapisi karbon, selanjutnya holder diletakkan di dalam sputter cooter untuk dilapisi dengan gold palladium selama \pm 120 detik. Morfologi partikel diamati dengan scanning electron microscopy (SEM) FEI Inspect S50 pada beberapa perbesaran dan dilakukan pengukuran terhadap beberapa partikel.

\section{Spektrum inframerah dari nanopartikel}

Spektrum Inframerah nanopartikel kitosan dibuat dengan metode cakram KBr. Sampel diamati dengan panjang gelombang $4000-400 \mathrm{~cm}^{-1}$.

\section{Jarak lebur}

Penentuan jarak lebur nanopartikel kitosan menggunakan alat Diferrential Thermal Apparatus (DTA). Diambil $\pm 5 \mathrm{mg}$ nanopartikel kitosan, kemudian dimasukkan ke dalam crusible pan tertutup. Pemeriksaan dilakukan pada suhu $50^{\circ} \mathrm{C}-300^{\circ} \mathrm{C}$ dengan kecepatan kenaikan suhu $10^{\circ} \mathrm{C}$ per menit.

\section{Redispersabilitas dan waktu pengendapan}

Redispersi partikel dilakukan dengan cara, $20 \mathrm{mg}$ sampel dilarutkan dalam $2 \mathrm{~mL}$ aquadest, kemudian dikocok biasa selama 10 detik. Dan selanjutnya, waktu pengendapan kembali dicatat.

\section{HASIL DAN PEMBAHASAN}

Pemeriksaan spektrum inframerah nanopartikel dilakukan untuk melihat interaksi antara kitosan dengan lioprotektan (maltosa, trehalosa dan sukrosa). Kitosan memiliki ikatan amida pada panjang gelombang $1655 \mathrm{~cm}^{-1}$. Dengan pernambahan lioprotektant, ikatan amida pada bilangan gelombang $1655 \mathrm{~cm}^{-1}$ hilang (Bhumkar \& Pokharkar, 2006). Hal ini disebabkan oleh tergantinya ikatan amida dengan ikatan hidrogen antara kitosan dengan lioprotektan (Gambar 1. F, G dan H; Panah biru) yang tidak terlihat pada campuran fisik (Gambar 1. E; Panah biru). Pada Gambar 2 menunjukkan hasil pemeriksaan jarak lebur nanopartikel. Pola termogram dengan satu puncak endotermik pada semua formula menunjukkan bahwa artesunat terjerap dalam sistem nanopartikel kitosan, kecuali pada formula kontrol tanpa penambahan lioprotektan. Pada formula menunjukkan pola termogram yang berbeda disebabkan sistem nanopartikel tidak stabil pada proses pengeringan beku sehingga artesunat terlepas dari sistem nanopartikel. Dari hasil ini dapat dikatakan bahwa sistem nanopartikel dengan penambahan lioprotektan dapat melindungi sistem nanopartikel selama pengeringan beku.

Dari hasil pengamatan jarak lebur menggunakan DTA pada nanopartikel artesunat-kitosan tanpa penambahan lioprotektan dan nanopartikel artesunatkitosan dengan penambahan lioprotektan dapat dilihat peran lioprotektan yang dapat menstabilkan koloid nanopartikel pada proses pengeringan beku. Hal ini terlihat dari hilangnya termogram kristalin artesunat 
yang seharusnya suhu lebur $\pm 130^{\circ} \mathrm{C}$ (Gambar 2. Panah merah) membentuk termogram amorf. Sedangkan pada nanopartikel dengan lioprotektan hanya tampak suhu lebur kitosan pada $\pm 150^{\circ} \mathrm{C}$ (Gambar 2. panah biru).

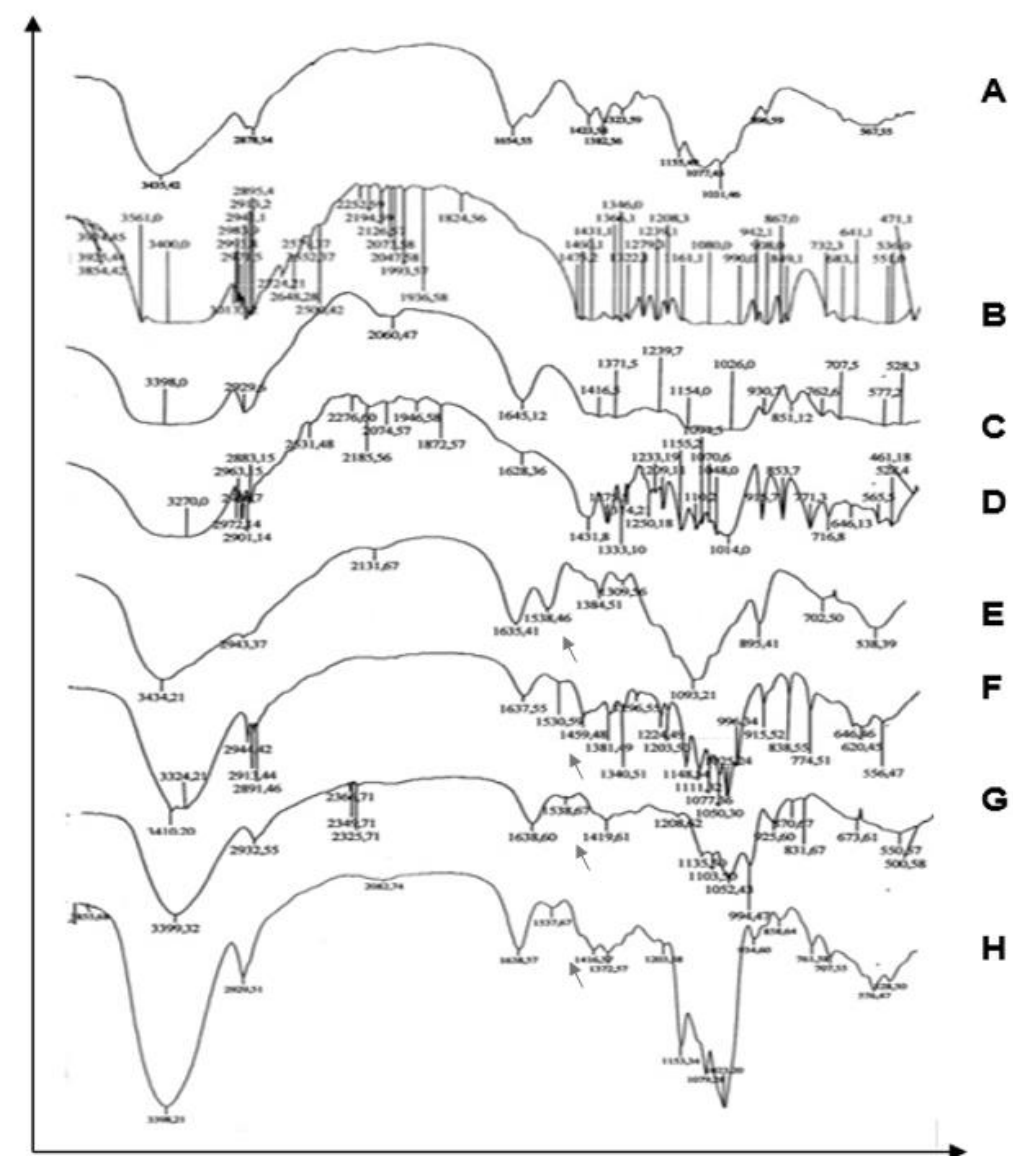

Gambar 1. Hasil pemeriksaan spektrum inframerah, kitosan(A), sukrosa (B), maltosa (C), trehalosa (D), partikel kitosan tanpa lioprotektan (kontrol) (E), partikel kitosan + trehalosa 2,5\% (F), partikel kitosan + sukrosa 2,5\% (G), dan partikel kitosan + maltosa $2,5 \%(\mathrm{H})$

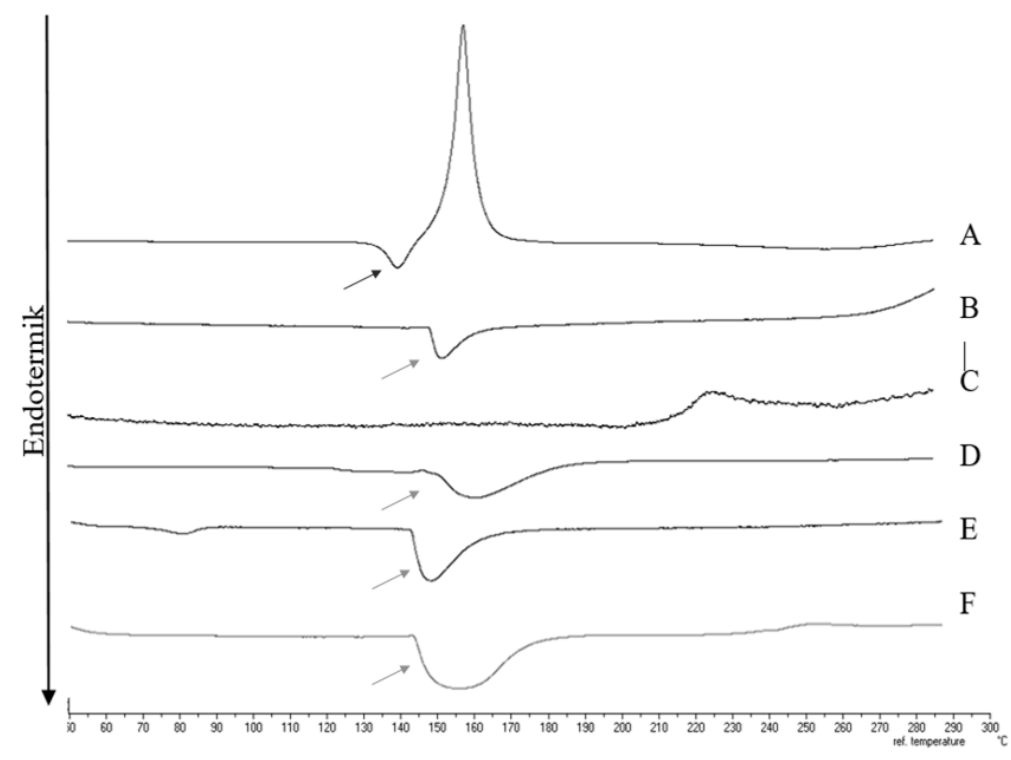

Gambar 2. Termogram DTA dari artesunat (A), kitosan (B), partikel artesunat-kitosan tanpa lioprotektan (C), partikel artesunat-kitosan dengan lioprotektan sukrosa 2,5\% (D), trehalosa 2,5\% (E) dan maltodektrin 2,5\% (F) 
Berdasarkan pemeriksaan ukuran dan morfologi nanopartikel artesunat-kitosan menggunakan Scanning Electron Microscope (SEM) antara formula dengan penambahan sukrosa dan maltodekstrin tampak beberapa perbedaan antara keduanya. Pada formula dengan menggunakan lioprotektan sukrosa terlihat bentukan partikel yang beragregasi. Sedangkan nanopartikel formula (T1) dilakukan pengamatan dengan menggunakan SEM, dan diperoleh bentukan nanopartikel yang beragregasi dan belum didapatkan gambaran partikel berbentuk sferis.
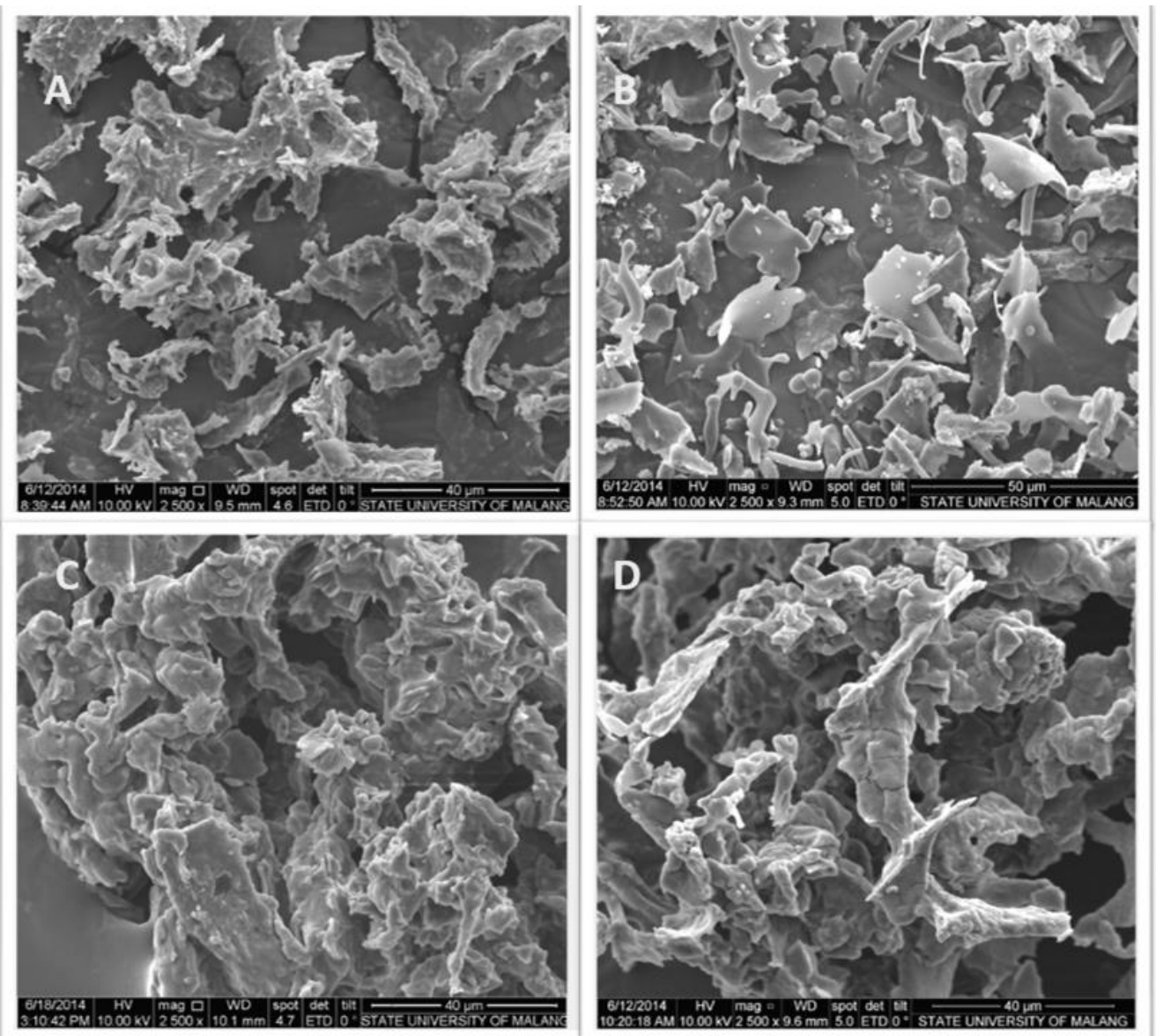

Gambar 3. Foto mikrograf Scanning Electron Microscope dari partikel artesunat-kitosan tanpa lioprotektan (A), partikel artesunat-kitosan dengan lioprotektan maltodektrin 2,5\% (B), trehalosa 2,5\% (C) dan sukrosa 2,5\% (D)

(pembesaran $2500 \mathrm{x}$ )

Pendispersian partikel dalam media air dan selanjutnya dilakukan pengamatan terhadap waktu partikel untuk mengendap, hasil pengamatan disajikan dalam Tabel 2. Pengamatan pada semua formula menunjukkan bahwa formula dengan jumlah lioprotektan lebih besar menunjukkan pendispersian
(Gambar 3B, panah merah). Pada nanopartikel artesunat-kitosan pada formula $\mathrm{K}$ didapatkan gambaran partikel yang beragregasi dengan permukaan yang kasar dibandingkan dengan nanopartikel artesunatkitosan dengan penambahan lioprotektan (Gambar 3A). Hal ini disebabkan oleh proses pembekuan pada pengeringan beku dapat menyebabkan kerusakan pada produk karena proses pengeringan beku menghasilkan berbagai tekanan selama pembekuan dan pengeringan. 
Tabel 2. Hasil evaluasi redispersabilitas dan waktu pengendapan nanopartikel artesunat-kitosan dengan dan tanpa penambahan lioprotektan pada berbagai kadar

\begin{tabular}{|c|c|c|}
\hline Formula & Pengamatan Visual & $\begin{array}{c}\text { Waktu Pengendapan } \\
\text { (s) }\end{array}$ \\
\hline $\mathrm{K}$ & Mudah terdispersi, membentuk cairan berkabut & 595 \\
\hline $\mathrm{S} 1$ & Mudah terdispersi, membentuk larutan berkabut & 432 \\
\hline $\mathrm{S} 2$ & Mudah terdispersi, membentuk cairan berkabut & 156 \\
\hline S3 & Mudah terdispersi, membentuk cairan berkabut & 14 \\
\hline $\mathrm{T} 1$ & Mudah terdispersi dan membentuk larutan berkabut & 164 \\
\hline $\mathrm{T} 2$ & Mudah terdispersi dan membentuk larutan berkabut & 41 \\
\hline M1 & Mudah terdispersi, membentuk cairan berkabut & 1441 \\
\hline M2 & Mudah terdispersi, membentuk cairan berkabut & 1415 \\
\hline M3 & Mudah terdispersi, membentuk cairan berkabut & 785 \\
\hline
\end{tabular}

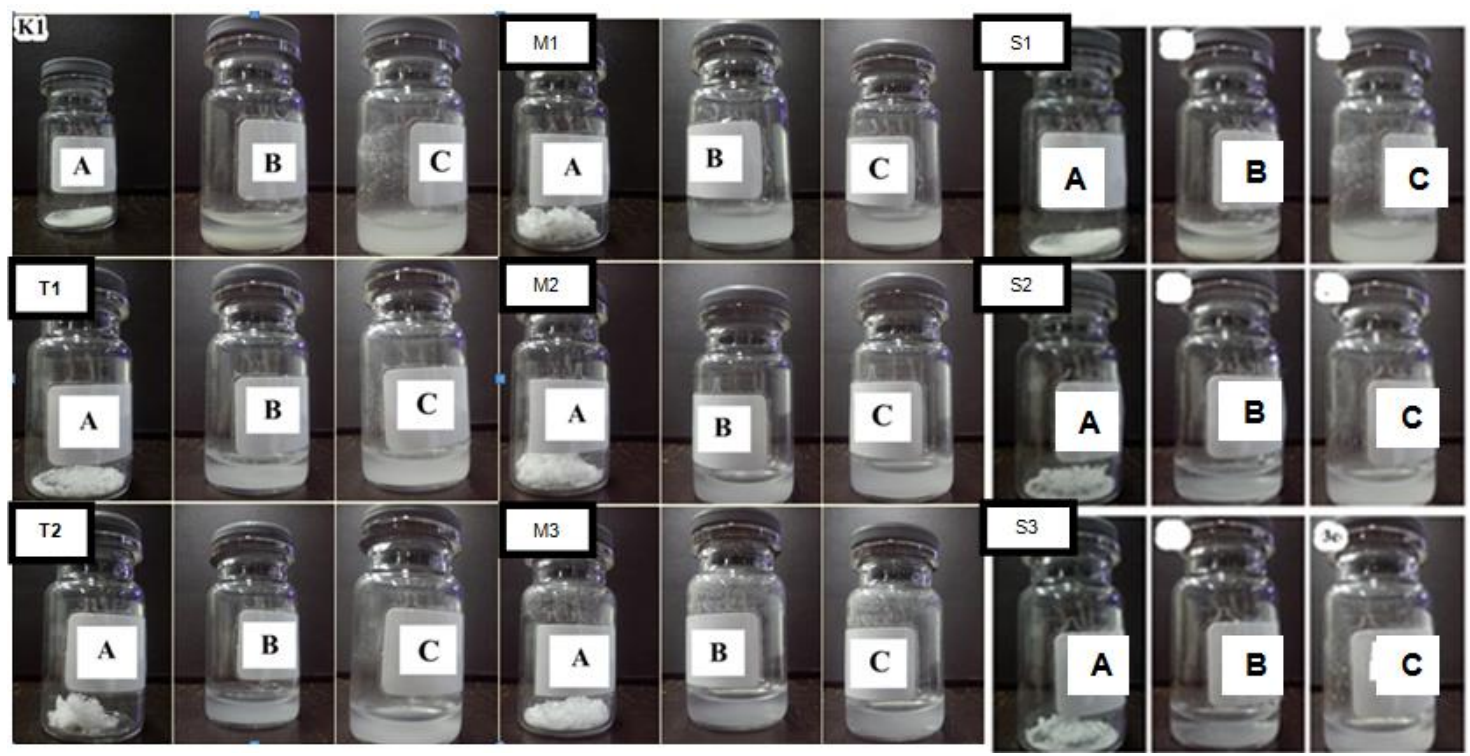

Gambar 4. Hasil evaluasi redispersabilitas nanopartikel artesunat-kitosan tanpa lioprotektan (K) dan dengan lioprotektan: trehalose (T), maltodekstrin (M) dan sukrosa (S) pada berbagai kadar. Kondisi padatan (A), kondisi setelah ditambah air (B), kondisi setelah dikocok (C).

\section{KESIMPULAN}

Nanopartikel dengan penambahan maltodekstrin menunjukkan bentukan partikel sferis dengan permukaan halus. Sedangkan pada nanopartikel artesunat-kitosan dengan trehalosa sudah didapatkan struktur permukaan partikel yang halusakan tetapi tidak memperoleh bentuk yang sferis. Analisa termal menggunakan DTA menunjukkan formula dengan penambahan lioprotektan sukrosa dan maltodekstrin mampu melindungi sistem nanopartikel, dibandingkan dengan formula tanpa penambahan lioprotektan. Penambahan lioprotektan pada nanopartikel artesunatkitosan mempengaruhi kemampuan redispersi partikel. Dengan penambahan konsentrasi lioprotektan semakin memperbaiki kemampuan redispersi nanopartikel.

\section{DAFTAR PUSTAKA}

Abdelwahed, W. Degobert, G., Stainmesse, S. \& Fessi, H. (2006). Freeze-drying of nanoparticles: Formulation, process and storage considerations. Advanced Drug Delivery Reviews; 58(15); 16881713.

Akhilesh, D., Faishal, G. \& Kamath, J. V. (2012). Review Article: Comparative Study of Carriers Used in Proniosomes. International Journal of Pharmaceutical and Chemical Sciences; 1(1); 164-173.

Amorij, J. P., Huckriede, A., Wilschut, J., Frijlink. H. \& Hinrichs, W. (2008). Development of stable influenza vaccine powder formulations: Challenges and possibilities. Pharmaceutical 
Research; 25(6); 1256-1273.

Bernard, C. \& Stainmesse, S. (2007). Freeze-Drying of Nanoparticles: Formulation, Process and Storage Considerations Freeze-drying of nanoparticles: Formulation, process.

Bhumkar, D. R. \& Pokharkar, V. B. (2006). Studies on effect of $\mathrm{pH}$ on cross-linking of chitosan with sodium tripolyphosphate: A technical note. AAPS PharmSciTech; 7(2); E138-E143.

Chang, L., Shepherd, D., Sun, J., Ouellette, D., Grant, K. L., Tang, X. C. \& Pikal, M. J. (2005). Mechanism of protein stabilization by sugars during freeze-drying and storage: Native structure preservation, specific interaction, and/or immobilization in a glassy matrix?. Journal of Pharmaceutical Sciences; 94(7); 1427-1444.

Corveleyn, S. \& Remon, J. P. (1996). Maltodextrins as lyoprotectants in the lyophilization of a model protein, LDH. Pharmaceutical Research; 146150.

Darwin, M. et al. (2007). The Science of Cryonics. History.

Date, P. V., Samad, A. \& Devarajan, P. V. (2010). Freeze Thaw: A Simple Approach for Prediction of Optimal Cryoprotectant for Freeze Drying. AAPS PharmSciTech; 11(1); 304-313.

Garg, A., Visht, S., Kumar, P., Sharma \& Kumar. (2011). Formulation, Characterization and Application on Nanoparticle: A Review. Pelagia Research Library; 2(2); 17-26.

Hasan, M. I. (2012). Modifikasi Nanopartikel Perak dengan Polivinil Alkohol untuk Meningkatkan Selektivitas dan Stabilitas Indikator Logam Tembaga $(\mathrm{Cu})$ : Uji Coba pada Makroalga Merah (Kappaphycus alvarezii). Skripsi; Fakultas Matematika dan Ilmu Pengetahuan Alam Universitas Indonesia, Depok.

Hirsjärvi, S. (2008). Preparation and Characterization of Poly ( Lactic Acid ) Nanoparticles.

Tiyaboonchai, W. (2003). Chitosan Nanoparticles: A Promising System for Drug Delivery; 11(3); 5166.

Varshosaz, J. \& Karimzadeh, S. (2007). Development of cross-linked chitosan films for oral mucosal delivery of lidocaine. Research in Pharmaceutical Sciences; 2; 43-52.

http://www.rps.mui.ac.ir/index.php/jrps/article/vie $\mathrm{w} / 26$. 